\title{
Conditions and Problems in the Implementation of National Education Standards in Rural Elementary Schools in the Context of Improving the Quality of Education
}

\author{
Novian Mashuri ${ }^{1}$, Osa Juarsa ${ }^{2}$, Rambat Nur Sasongko ${ }^{2^{*}}$ \\ ${ }^{1}$ Student of Education Faculty, Universitas Bengkulu, Indonesia \\ ${ }^{2}$ Professor of Education, Faculty of Education, Universitas Bengkulu, Indonesia
}

DOI: $10.36348 /$ jaep.2021.v05i01.002

| Received: 08.01.2021 | Accepted: 19.01.2021 | Published: 23.01.2021

*Corresponding author: Rambat Nur Sasongko

\section{Abstract}

Quality schools are organized based on the National Education Standards (NES). Unfortunately, many schools that are held do not refer to these NESs. There are schools that have not implemented these national standards thoroughly. This also includes elementary school levels that have not been implemented thoroughly, especially schools in rural areas. This study aims to describe the application of national education standards in rural elementary schools. This study uses a policy evaluation description method. This research was conducted at the elementary school level in North Bengkulu Regency, Bengkulu Province, Indonesia. Data collection techniques with checklists, interviews, observation, and documentation study. The data were analyzed descriptively quantitatively. The results showed that the conditions for implementing the national education standards in rural elementary schools had not been met effectively. School conditions have not reached the target of the national education standard. This condition has a negative impact on the image of rural schools. There are a number of problems, including lack of community awareness and contribution, inadequate condition of facilities and infrastructure, limited funds, lack of concern and contribution from the government. Suggestions to the education administering authorities to plan the fulfillment of NES in rural elementary schools in a concrete and operational manner.

Keywords: National education standards, primary schools, rural areas.

Copyright ( ) 2021 The Author(s): This is an open-access article distributed under the terms of the Creative Commons Attribution 4.0 International License (CC BY-NC 4.0) which permits unrestricted use, distribution, and reproduction in any medium for non-commercial use provided the original author and source are credited.

\section{INTRODUCTION}

Quality elementary schools are schools that are organized according to the national education standards (NES). Indonesia already has a national policy in the form of national education standards. This national standard has been stipulated by Government Regulation no. 19 of 2005 on National Education Standards (NES). Government Regulation No. 19 of 2005 concerning National Education Standards (NES) regulates content standards, processes, competence of graduates, management, educators and education personnel, facilities and infrastructure, financing, and education assessment. The eight standards have been operationalized into ministerial regulations in more detail and detail according to school levels.

NES is the minimum criterion regarding the education system in all regions of Indonesia. These national standards are aimed at guaranteeing and controlling the quality of education in the context of the intellectual life of the nation and shaping the character and civilization of the nation with dignity. The function of this standard is as a basis for planning, implementing, and supervising education in the context of realizing quality national education [1].

This NES is the main guideline for school administration [2]. Each school in managing education must be guided by the national education standards. Likewise, the school's final assessment, such as school accreditation, refers to the implementation of national education standards. In America, national standards of education do not come and are set by the government [3]. However, it emerged from various national bodies, such as the National Council of the Teachers of Mathematics (NCTM) which published mathematics teaching standards in 1989. The publication of these standards subsequently inspired the formation of national education standards. This condition illustrates that the national education standards in Indonesia appear to be based on "top down". The central government is more dominant in regulating education delivery [4]. 
Novian Mashuri et al., J Adv Educ Philos, Jan, 2021; 5(1): 16-21

The results showed that the application of national standards has positive aspects. For example Sasongko's research [5]; Sasongko [6]; and Rusdiana and Nasihudin [7] show that the national education standard has advantages, among others: (a) the implementation of schools throughout Indonesia is the same reference, (b) the quality of education at various levels of school is guaranteed, (c) the community becomes confident in send their children to school, because the standards are the same, (d) the quality of education is evenly distributed throughout Indonesia, and (e) it can increase the enthusiasm of schools to be more standardized nationally.

NES in Indonesia has been revised through Government Regulation no. 32 of 2013 concerning the revision of national education standards. This revision is proof of commitment from the government so that the delivery of this education can be in accordance with the provisions of the applicable laws. Schools as one of the formal institutions that have the task of providing education must also be guided by national education standards, at various levels of school.

NES is the minimum criterion regarding various relevant aspects in the implementation of the national education system and must be fulfilled by education providers and / or education units in all jurisdictions of the Republic of Indonesia (GR No. 19 of 2005 and GR No. 32 of 2013). The function of this national standard is to serve as the basis for planning, implementing and supervising education in the context of realizing quality national education. The aim of the national education standards is to ensure the quality of national education in order to educate the nation's life and to shape the character and civilization of the nation with dignity [8].

The NES set by the government consists of eight standards, namely content standards, process standards, graduate competency standards, teacher and education staff standards, facilities and infrastructure standards, management standards, financing standards and educational assessment standards. These eight standards are an integral part that must be applied by education units to ensure the quality of education management [1]. Quality education management can have a positive impact on quality graduates $[8,9]$.

A quality school is in accordance with established national standards [2, 3]. Burton illustrates in America that the states are almost entirely compliant with the standards set by the government [3]. This provides benefits for the community to not hesitate for the education of their children and the implementation of education in each education unit is in accordance with government policy [8].

NES is an obligation to implement. This is based on the rationale that if national standards are not applied in schools, then these schools are certainly not standard. The impact is in the form of low learning achievement, low graduation rates, schools are less able to compete with other schools, and lack of community image and trust in schools. This condition can cause schools to not get prospective students who register. Thus, these schools may be closed and not allowed to provide education by the government [10].

A preliminary study in Bengkulu province shows that the government has not officially conducted research on the application of national education standards. Likewise, the local education office has not conducted a similar study. Research on the application of national standards in elementary schools (ES) is very important as a basis for improving and increasing the quality of education starting from the basics. This research is very necessary, so that theoretically and practically it is useful for the benefit of improving ES performance. Apart from this, the unresolved real problems relating to the application of national standards in elementary schools can be resolved appropriately and accurately.

This research departs from the problem that in rural elementary schools the implementation of NES has not been implemented properly. This research problem can be formulated as follows: "What are the conditions and problems in implementing national education standards in rural elementary schools?" This problem can be described into two sub-problems, namely: (1) How is the description of the application of national education standards in rural elementary schools?

The purpose of this study was to describe the conditions and problems of implementing the national education standards in elementary schools. Its specific objectives are to: (1) describe the implementation of national education standards at the rural primary school level, and (2) describe the real problems faced by rural elementary schools in implementing national standards in order to improve school quality.

It is hoped that this research can be used as input for the improvement and enhancement of policies for implementing national education standards in rural elementary schools, local education offices, improving primary school performance, improving the roles of school principals, teachers and support staff, and improving the design of school quality.

\section{METHODS}

This study uses a descriptive method of policy evaluation [11]. The study aims to describe the application of national education standards in rural elementary schools. A descriptive approach using detailed evaluative descriptions of the application of national education standards at the primary school level and real problems in the field. 
Novian Mashuri et al., J Adv Educ Philos, Jan, 2021; 5(1): 16-21

The research site was conducted at a rural elementary school in the province of Bengkulu, Indonesia. The study population was the principal of public elementary schools in Bengkulu Utara district, amounting to 254 people or schools, consisting of 230 public elementary schools and 24 private elementary schools. The study sample was selected with a purpose by considering the representation of schools, locations, and types of data collected [11] The total sample was 130 school principals, consisting of 115 from public schools and 15 from private schools.

The data collection technique was carried out by means of a checklist questionnaire and short entries about the problems faced. A checklist questionnaire was used to analyze the implementation of national education standards in schools. This questionnaire contains the achievement of the application of national education standards in schools, which is described as a percentage. The questions asked about the achievement of the implementation of the 8 standards, namely the passing standards, content, process, teachers and education personnel, facilities and infrastructure, financing, management, and assessment. Apart from this, it was also asked about the problems faced in the application of these national standards.

Data were analyzed using descriptive statistics, namely by analyzing the fulfillment of national education standards in schools. The application of national education standards is said to be fulfilled, if it is in accordance with the national education standard policies that have been established by the government
(Government Regulations No. 19 of 2005 and No. 32 of 2013). Evaluative analysis using descriptive statistical techniques (percentage and mean) [11].

\section{RESULTS AND DISCUSSION Research Results}

a. Conditions for Implementing National Education Standards in Rural Elementary Schools

NES must be implemented in both public and private elementary schools. This is because besides being a national policy, it can also improve the quality of education in schools. The application of this NES can provide positive values for schools, especially in producing graduates into standards, curriculum according to national standards, quality learning activities, teachers and staff are fulfilled, facilities and infrastructure become complete, finance becomes sufficient, management system becomes good, and assessment according to national standards.

The results showed that the achievement of implementing national education standards in rural primary schools was not in accordance with the NES. The average fulfillment of national standards is $83.62 \%$. If you look at the standard criteria for applying NES, then the achievement is in the category of almost approaching the national standard. This condition means that it does not provide positive values for improving the quality of primary schools in rural areas. In detail, the results of the research can be presented in the following table.

Table-1: Condition of NES Implementation in Rural and Private ES

\begin{tabular}{|l|l|l|l|l|l|l|l|}
\hline \multirow{2}{*}{ No } & National Education Standards Components & \multicolumn{2}{|l|}{ State school } & \multicolumn{2}{l|}{ Private school } & \multicolumn{2}{l|}{ Average } \\
\cline { 3 - 7 } & & $\mathbf{n}$ & $\mathbf{\%}$ & $\mathbf{n}$ & $\mathbf{\%}$ & $\mathbf{n}$ & $\mathbf{\%}$ \\
\hline 1 & Passing standards & 115 & 98.0 & 15 & 96.0 & 130 & 97.0 \\
\hline 2 & Standard content & 115 & 76.0 & 15 & 72.0 & 130 & 74.0 \\
\hline 3 & Process standard & 115 & 84.0 & 15 & 88.0 & 130 & 86.0 \\
\hline 4 & Teacher and education staff standards & 115 & 86.0 & 15 & 78.0 & 130 & 82.0 \\
\hline 5 & Standard facilities and infrastructure & 115 & 76.0 & 15 & 72.0 & 130 & 74.0 \\
\hline 6 & Financing standards & 115 & 88.0 & 15 & 82.0 & 130 & 85.0 \\
\hline 7 & Management standards & 115 & 92.0 & 15 & 90.0 & 130 & 91.0 \\
\hline 8 & Assessment standard & 115 & 84.0 & 15 & 76.0 & 130 & 80.0 \\
\hline & Average & 115 & 85.50 & 15 & 81.75 & 130 & 83.62 \\
\hline
\end{tabular}

Based on Table-1 above, it can be explained that the achievement of NES in public ES is better than in private ES. The average achievement at Public ES is $85.50 \%$, while in private ES it is $81.75 \%$. The two types of schools have the same status, that is, they are in the category of almost effective or almost standard schools. This condition means that schools have not been able to meet the national education standards. Primary schools still have to make efforts to improve which aspects of the NES components need to be improved.

When viewed from the NES component, the highest achievement of NES application is the passing standard component (97\%) and management standard (91\%). The NES components with low achievement were content standards (school curriculum) (74\%) and facilities and infrastructure standards (74). The two NES components fall into the category of less effective or less standardized. Meanwhile, process standards $(86 \%)$, teacher and education staff standards $(82 \%)$, financing standards $(85 \%)$, and assessment standards $(80 \%)$ were categorized as nearly effective or nearly standard.

b. Problems of Implementing NES in Rural Elementary Schools 
Novian Mashuri et al., J Adv Educ Philos, Jan, 2021; 5(1): 16-21

The lack of fulfillment of NES in rural primary schools is due to a number of problems they face. ES in implementing NES experiences a number of real problems. This can be seen from the achievement of the NES percentage. Almost no school has reached the target of one hundred percent and is categorized as the national standard school. Elementary school principals generally convey a number of problems faced, why schools have not been able to fulfill NES in full.

There are several real problems in schools in implementing NES, which are explained in the following table.

Table 2: Real Problems in the Implementation of NES in ES

\begin{tabular}{|l|l|l|l|l|l|l|l|}
\hline No & Kinds of problems & State schools & \multicolumn{2}{l|}{ Private schools } & \multicolumn{2}{l|}{ Total } \\
\cline { 3 - 7 } & & $\mathbf{f}$ & $\mathbf{\%}$ & $\mathbf{f}$ & $\boldsymbol{\%}$ & $\mathbf{f}$ & $\mathbf{\%}$ \\
\hline 1 & Concern and contribution from the principal is lacking & 8 & 6.15 & 0 & 0 & 8 & 6.15 \\
\hline 2 & Less concern and contribution from teachers & 26 & 20.00 & 4 & 3.07 & 30 & 23.07 \\
\hline 3 & Less concern and contribution from staff education & 32 & 24.61 & 8 & 6.15 & 40 & 30.76 \\
\hline 4 & Less concern and contribution from school committee & 98 & 75.38 & 15 & 11,54 & 113 & 86.92 \\
\hline 5 & Less concern and contribution from head of the education office & 101 & 77.69 & 15 & 11.54 & 116 & 89.23 \\
\hline 6 & Less concern and contribution from local government & 92 & 70.77 & 15 & 11.54 & 107 & 82.31 \\
\hline 7 & Less concern and contribution from central government & 112 & 86.15 & 15 & 11.54 & 127 & 97.69 \\
\hline 8 & Less concern and contribution from general community & 115 & 88.46 & 15 & 11.54 & 130 & 100.0 \\
\hline 9 & $\begin{array}{l}\text { Lack of guidance and supervision of the implementation of NES } \\
\text { in schools }\end{array}$ & 42 & 32.31 & 12 & 9.23 & 54 & 41.54 \\
\hline 10 & The condition of school facilities and infrastructure is lacking & 115 & 88.46 & 15 & 11.54 & 130 & 100.0 \\
\hline 11 & Insufficient school financial conditions & 115 & 88.46 & 15 & 11.54 & 130 & 100.0 \\
\hline 12 & $\begin{array}{l}\text { Others (lack of continuous evaluation, lack of coordination / } \\
\text { meeting of leaders, less focus on meeting NES) }\end{array}$ & 42 & 32.31 & 6 & 4.61 & 48 & 36.92 \\
& & & & & & \\
\hline
\end{tabular}

Based on the data in the table above, it can be interpreted that it turns out that both public and private elementary schools all have a number of problems in implementing NES. The most important problems (with many frequencies), include: (1) lack of concern and contribution from the surrounding community in helping to fulfill the NES implementation (100\%), (2) the lack of facilities and infrastructure conditions for each school (100\%), (3) the school's financial condition is inadequate for school needs to meet the achievement of NES (100\%), (4) lack of concern and contribution from the central government in overcoming NES fulfillment in schools (97.69\%), lack of concern and contribution from the head of the education office in overcoming NES compliance in schools (89.23\%), (5) lack of concern and contribution from the school committee in overcoming NES fulfillment in schools (86.92\%), (6) lack of concern and contribution from local governments in overcoming NES fulfillment in schools $(82.31 \%)$.

Other problems faced by schools are less frequent (below 50\%), such as: (1) lack of guidance and supervision of schools in implementing NES (41.54\%), (2) other problems (lack of continuous evaluation, coordination / lack of leadership meetings, lack of focus on meeting NESs (36.92\%), (3) lack of concern and contribution of education personnel in overcoming NES compliance in schools $(30.76 \%)$, (4) lack of concern and contribution from teachers in overcoming NES fulfillment in schools (23.07\%), and (5) lack of concern and contribution from the principal in overcoming NES fulfillment in schools $(6.15 \%)$.
The real problems faced by these schools are a common phenomenon in schools. Even so, it seems clear that these problems occur in all schools, such as: (1) lack of concern and contribution from the surrounding community in helping to meet the NES implementation, (2) the lack of facilities and infrastructure conditions for each school, and (3) the condition inadequate school finances for school needs to meet NES achievement.

\section{DISCUSSION}

The results of the research show that the implementation of national education standards in rural primary schools, both public and private, is not yet in accordance with government policy standards. The average fulfillment of national standards is $83.62 \%$, including in the almost effective category and including almost standard schools. Thus, the implementation of NES in ES is not in accordance with government policy. The standard from the government, namely the application of NES in each school is completely met or one hundred percent. If each school can fulfill the full and comprehensive of the eight national standards, it can be called a National Standard School (SSN) [4, 12].

The analysis of the results of the achievement of the application of NES in State ES is better than in private ES, occupying the same category position, which is almost standard. Both of them achieved NES for Public ES on an average of $85.50 \%$, while in private ES, the average was $81.75 \%$. The two types of schools have the same status, that is, they are in the category of almost effective or almost standard schools. Both have not been able to achieve the national education 
Novian Mashuri et al., J Adv Educ Philos, Jan, 2021; 5(1): 16-21

standard. In this condition, both types of schools must continue to strive in order to be able to improve the full implementation of NES in all components $[11,13]$.

The results of Sasongko, Somantri, and Wachidi [1] 's research on the implementation of NES at various levels of school illustrate that public and private schools tend to have different results. Public schools have a higher level compared to private schools in implementing NES in schools. However, this research has the same category and NES application status. Likewise for the NES component, each component has different results Sasongko, Somantri, and Wachidi, 2018; Sasongko and Fetrianggi, 2020. This research also shows the same results, such as the achievement of implementing NES is high and some are low. The NES component with the highest achievement was the component of graduation standards (97\%) and management standards (91\%). The NES components with low achievement were content standards (school curriculum) (74\%) and facilities and infrastructure standards (74). In process standards $(86 \%)$, teacher and education staff standards (82\%), financing standards $(85 \%)$, and assessment standards $(80 \%)$, are medium standards and fall into the category of nearly effective or nearly standard.

In fact, when compared with other studies that examine the application of NES in schools, such as Triwiyanto [14]; Sasongko [5]; Sasongko [6]; Sasongko and Sahono [8]; Rusdiana and Nasihun [7]; Sasongko [2]; and Burton [3] provide research results that the achievement of the application of national standards has not been able to achieve full standard compliance. Every school has a number of problems and tough work to fulfill this national policy.

Research analysis by Sasongko and Sahono [8] examines more broadly and provides research results that the application of national education standards has a strong relationship with high school accreditation scores, high exam scores, good community image, and high school achievement. This study does not examine such details. This study does not examine the achievement of implementing NES with other aspects such as the quality of learning outcomes, school performance, school accreditation scores, community image, school achievement, and so on. This study focuses on research activities to evaluate the implementation of NES policies at the elementary school level [14].

The results of the implementation of NES in each school have different characteristics from one school to another [10]. The characteristics of school principals, teachers, and education staff contribute significantly to the results of the study [1]. Therefore schools also have a number of problems in implementing NES.

This condition means that at the elementary school level, there are a number of problems in implementing NES. The problems that are urgent to be addressed include: (1) lack of concern and contribution from the surrounding community in helping to fulfill the NES implementation, (2) the condition of the facilities and infrastructure that are inadequate for each school, (3) the school's financial condition is inadequate for school needs in order to meet the NES achievement, (4) lack of concern and contribution from the central government in overcoming NES fulfillment in schools, lack of concern and contribution from the head of the education office in overcoming NES fulfillment in schools, (5) lack of concern and contribution from the school committee in overcoming compliance NES in schools, and (6) lack of concern and contribution from local governments in overcoming NES fulfillment in schools. This problem seems to need to be prioritized to be immediately resolved through various means.

At the national level, the implementation of School Based Management (SBM) as the best solution in managing quality schools has not been able to provide optimal results in every school [3]. Each school has its own problems in management to improve school quality. School-based management that has been implemented in schools is actually the basis for quality that is given authority to schools [15]. Implementation of school-based management and national education standards each have unique problems. Examples of local government policies, especially the city / district education offices, are not yet fully serious in fulfilling the national standard for fulfilling the education budget of at least $20 \%$ of the regional budget. The application of school-based management which has not been fully recognized as effective in overcoming the problems of education in schools has a number of problems [2-4]. There are a number of problems that arise when schoolbased management is implemented in schools, such as the school's lack of understanding of school-based management, the education office does not care, the school is running from the road, school staff perform routine work, and lack of control or serious guidance from the authorities.

Analysis of Sasongko and Sahono's [2] research on accelerating the fulfillment of NES also shows that many factors affect the achievement of national standards at various levels of schools, such as school principals and their staff who do not understand how to meet standards in a better direction, financial problems that support compliance with standards national, and the problem of insufficient facilities and infrastructure. In this condition, there should be concern from the local education office to take concrete steps to overcome problems in implementing NESs that have not reached national standards.

\section{SUMMARY}

The research conclusions indicate that the conditions for implementing NES in rural primary schools have not been effectively fulfilled. This means that the government policy regarding the obligation to 
Novian Mashuri et al., J Adv Educ Philos, Jan, 2021; 5(1): 16-21

implement NES has not really been implemented by schools effectively. The conditions for implementing national standards are not yet standardized. The condition of public and private schools did not have a significant difference in the results of the implementation.

The lack of fulfillment of the NES is due to a number of problems, such as a lack of concern and contribution from the surrounding community in helping to fulfill the NES implementation, lack of adequate facilities and infrastructure, inadequate school financial conditions, lack of concern and contribution from central and local governments, as well as school committees in overcome NES compliance in schools.

Suggestions to the educational administering authorities, both school principals, heads of education offices, regional and central government leaders who are in power should be able to help overcome NES fulfillment in a more concrete and operational manner. Each school should be assisted with technical assistance, provide adequate facilities and infrastructure, as well as adequate finance, so that it can be used to fulfill the NES in full.

\section{ACKNOWLEDGMENTS}

Expressed appreciation and gratitude to the Ministry of Research and Technology of the Republic of Indonesia who has provided funds for master thesis research. To the Institute for Research and Community Service, University of Bengkulu, thank you for all services for the completion of this research.

\section{REFERENCES}

1. Sasongko, R. N., Somantri, M., \& Wachidi. (2018). The New Challenges of Implementation of School Principals Standards in the Era of Asean Economic Communities (AEC). International Journal of Recent Scientific Research. 9(9A), 28733-28736. http://www.recentscientific.com /sites/default/files/11762-A- 2018.pdf

2. Sasongko, R. N. (2019). Determinants of the Level of Application of the National Education Standards at Various School Levels. Education Manager: Postgraduate Educational Management Scientific Journal, 13(1), 63-72. http://ejournal.unib.ac.id/i ndex.php/manajerpendidikan

3. Barton, P. (2009). National Education Standards: Getting Beneath the Surface. New Jersey: Policy Information Center. https://www.ets.org/Media/Research/pdf/PICNAT EDSTAND.pdf

4. ACDP. (2013). Evaluation of International Standard Schools in Indonesia. Jakarta: Ministri of Education and Culture.

5. Sasongko, R. N. (2015). Strategies to Overcome Poor Madrasahs through the Development of Collaborative-Based Management Models
(Educational Action Research at Various Levels of Madrasahs in Bengkulu Province). Madania: Journal of Islamic Studies. 19(2), 185-194.

6. Sasongko, R. N. (2018). The Implementation of National Standards of Education for School Quality Improvement Facing the 21st Century (Descriptive Evaluative Studies in Various Levels of Schools in Bengkulu Province of Indonesia).

International Journal of Current Research in Life Sciences. 7(8), 2647-2651. http://www.ijcrls.com/sites/defa ult/files/issuespdf/01660..pdf

7. Rusdiana, A., \& Nasihudin, N. (2018). The Implementation of National Standard-Based Curriculum in Private Islamic Higher Education: Leadership Impact. Jurnal Pendidikan Islam, 4(1), 87-98.

8. Sasongko, R. N., \& dan Sahono, B. (2018). Accelerating the Fulfillment of NESs through the Development of a Performance Audit-Based School Development Model. Bengkulu: Research Report on LPPM UNIB.

9. Septarina, L., \& Sasongko, R. N. (2019). Quality Management: Impact of Leadership Mobilization on Institutional Quality. International Journal of Research Science \& Management, 6(5), 1-8. http://www.ijrsm.com/issues\%20pdf\%20file/Arch ive-2019/May-2019/1.pdf

10. Bandur, A. (2009). The Implementation of School Based Management in Indonesia: Creating Conflict in Regional Level. Journal of NTT Studies, 1(1), 16-27.

11. Burn, R. B. (2009). Introduction to Research Methods. Sidney: Longman.

12. Bosshardt, W., \& Walstad, W. (2014). National Standards for Financial Literacy: Rationale and Content. The Journal of Economic Education, 45(2), 67-85.

13. Burke, L., \& Marshall, J. A. (2010). Why National Standars Wont Fix American Education: Misaligment of Power and Incentives. https://www.heritage.org/research/report/2010/05

14. Sasongko, R. N., Ismail, A. H. J., \& Sahono, B. (2019). The Portrait of Provision of Indonesian Elementary School Teachers in Malaysia. Journal of Advances in Education and Philosophy. 3(10), 357-363. https://scholarsmepub.com/jaep-310/

15. Triwiyanto, T. (2013). National Education Standards as Indicators of Quality in Education Management Services. Journal of Educational Sciences. 19(2), 44-52.

16. Sasongko, R. N., \& Fetrianggi, R. (2020). An Analysis of the Management of Poor Student Assistance to Improving Learning Achievement. International Journal of Research Science \& Management, 7(6), 32-38. http://www.ijrsm.com/issues\%20pdf\%20file/Arch ive-2020/June-2020/6.pdf 